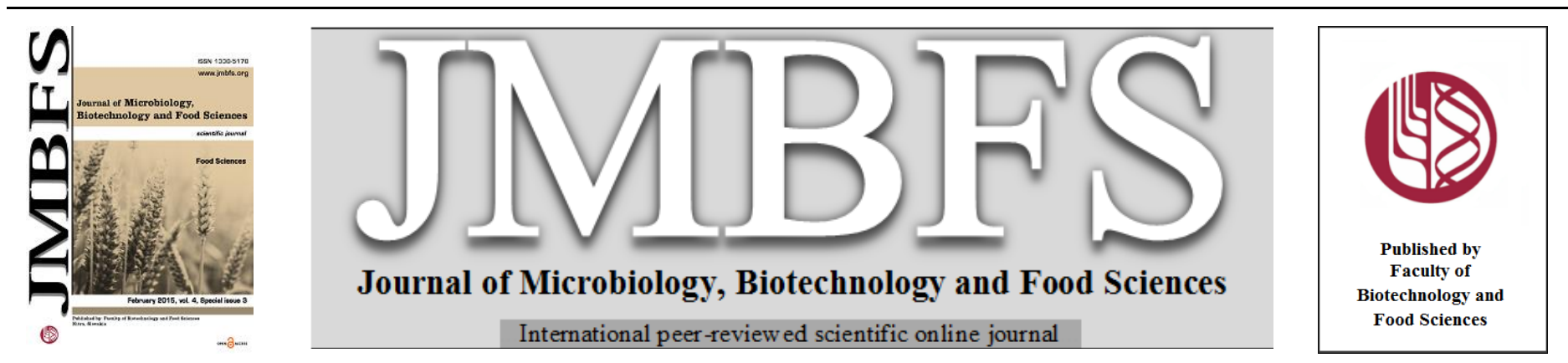

\title{
PROTEOLYSIS DURING MANUFACTURE AND RIPENING/STORING OF “OLOMOUCKÉ TVARŮŽKY" CHEESE (PGI)
}

\author{
Vendula Pachlová ${ }^{* 1}$, František Buňka ${ }^{1}$, Leona Buňková2
}

Address(es): Ing. Vendula Pachlová, Ph.D.

${ }^{1}$ Tomas Bata University in Zlín, Faculty of Technology, Department of Food Technology, nám. T. G. Masaryka 5555, 760 01, Zlín, Czech Republic, phone number: +420576033007.

${ }^{2}$ T omas Bata University in Zlín, Faculty of Technology, Department of Environment Protect Engeneering, nám. T. G. Masaryka5555, 760 01, Zlín, Czech Republic.

*Corresponding author: pachlova@ft.utb.cz

doi: $10.15414 /$ jmbfs.2015.4.special3.130-134

\section{ARTICLE INFO}

Received 1. 12.2014

Revised 6. 12. 2014

Accepted 7. 12. 2014

Published 2. 2. 2015

Regular article

open $\partial_{\text {ACCESS }}$

\section{ABSTRACT}

Twenty-two free amino acid (FAA) concentrations were observed during manufacture ( $1 \mathrm{st}, 3 \mathrm{rd}$ and 7 th days of production) and ripening period ( 42 days storing at $8^{\circ} \mathrm{C}$ ) of "Olomoucké tvarůžky" (PGI, smear acid cheese). Sensory attributes were also analysed during ripening period. The free amino acids were determined by means of ion-exchange chromatography. The development of the individual FAA content positively correlated with the ripening period $(\mathrm{r}=0.7734-0.9229 ; \mathrm{P}<0.01)$. The results gave information about the development precursors (FAA) of typically sensory active compound in "Olomoucké tvarůžky" (PGI) during its production and especially ripening. In conclusion, we found that free amino acid concentration as finally products of proteolysis are positive with improved flavour.

Keywords: Proteolysis, free amino acid, cheese, ripening

\section{INTRODUCTION}

„Olomoucké tvarůžky“ is a special type of Czech soft smear-ripening acid cheese with Protected Geographical Indication (PGI). "Olomoucké tvarǔžky" (PGI) gains its distinctive flavour by means of the microbial enzymatic apparatus. The intensity of the flavour depends on the maturity degree - ranging from mild to distinctive, piquant and even pungent. The microflora responsible for the abovementioned changes in flavour also makes the typical gold to yellowish/orange smear on the surface of this cheese (Palencia et al. 2004, Williams, et al., 2004, Rattray and Fox, 1999)

Standard curd (moisture content $68-66 \%$ w/w) with modified acidity within $\left(120-140^{\circ} \mathrm{SH}\right)$ is mixed with a pure dairy culture (complex consortium consisted especially of Brevibacterium linens, Candida valida, Pedioccocus acidilactici) and formed into a desired shape. Within 2 to 4 days (called "drying" at $\approx 20^{\circ} \mathrm{C}$ ), the growth of microflora and formation of yeast film on the surface of the cheese can be observed. Subsequently, the surface of the cheese is rinsed with water. The cheeses treated this way are left to ripen for another 2 to 4 days to allow a sufficient growth of smear culture (mainly Brevibacterium linens). After the ripening, the cheeses are wrapped into semi-permeable clingfilm and are left to ripen at a temperature of $<10^{\circ} \mathrm{C}$ (usually in chain stores).

Smear cheese typically ripens from the surface in towards the middle. Apart from the basic mesophilic culture of lactic acid bacteria (LAB - coming from the raw material-acid curd), aerophilic smear culture is also involved in the ripening (Fox et al., 2004). The surface of the cheese is covered with a gold/yellowish smear coat which contains microorganisms of various origin (starters - SLAB and also non-starters - NSLAB), including coryneform bacteria (Brevibacterium), gram-positive cocci (Lactococcus) and yeasts (Torulopsis, Candida, Oospora). Pediococcus acidilactici is often used as protective culture which decreases the growth of many contaminating microorganisms primarily due to the production of lactic acid and secretion of bacteriocins. The growth of yeast within "drying" ( 2 to 4 days after the formation of curd) leads to neutralisation of the cheese surface (increase in $\mathrm{pH}$ ) due to oxidation of lactic acid to $\mathrm{CO}_{2}$ and water. The decrease in acidity of the cheese surface and removal of the yeast film (by rinsing with water) stimulate the subsequent growth of the desired smear bacteria (Irlinger et al., 2012; Bockelmann et al., 2005). During the ripening period of "Olomoucké tvarůžky", a significant increase in Brevibacterium linens, which forms a predominant part of the microflora, can be observed on the surface of the cheese (Rattray and Fox, 1999). B. linens produces orange-brown pigments and causes, together with other microorganisms (including NSLAB), the characteristic colouring of the cheese surface (Fox et al.,
2004). The proteolytic apparatus of the microflorapresent affects the release of free amino acids (FAA), which are important precursors for the subsequent flavour development. B. linens has a very active proteolytic system which is involved in cheeseripening (Williams et al.,2004). By means of transamination, FAA can be changed into corresponding $\alpha$-ketoacids and subsequently converted into carboxylic acids, methylaldehyde, 2- and 3-methylbutanal and 2methylpropanal, which have a noticeable effect on the flavour of the final product (Yvon and Rijen, 2001). Moreover, B. linens can degrade amino acids while producing ammonia, which is a typical reaction in smear cheese. Also, the flavour of smear cheese is significantly influenced by elimination reactions, e.g. of methionin into methanethiol with a subsequent conversion (oxidation) to dimethyl disulfide and dimethyl trisulfide (Yvon and Rijen, 2001, Sablé and Cottenceau, 1999, Smit et al., 2000,Smit et al. 2005). B. linens is capable of metabolism of cysteine or cystine to hydrogen sulfides. However, this activity is lower in comparison with the formation of dimethyl disulfide and dimethyl trisulfide (Rattray and Fox, 1999). B. linens together with yeasts and micrococci converse tyrosine to cresol (Yvon and Rijen, 2001). Furthermore, some FAA can directly influence the flavour.

The aim of this study was (i) to describe of proteolytic changes (by means of free amino acid content) during the production phase (7 days) and ripening/storing (42 days) of smear cheese "Olomoucké tvarůžky" (PGI) and (ii) to perform a correlation analysis of the dependence of free amino acid content and the data from the sensory analysis on the ripening period.

\section{MATERIAL AND METHODS}

\section{Cheese production and sampling}

The samples of "Olomouckét varůžky" (PGI) were randomly taken from three batches made by a traditional manufacturer (A.W. Ltd., Loštice, Czech Republic) during standard production. The manufacture protocol was same as in Pachlová et al. (2013). The basic raw material for the production of "Olomoucké tvarůžky" (PGI) was acid curd (quark) from skimmed milk. The acidity of the quark was modified by the mixture of sodium bicarbonate and calcium carbonate in order to reach the values ranging between $120-140^{\circ} \mathrm{SH}$.

Subsequently, the acid curd (quark) was standardised to reach the desired moisture content (66-68\%). The mixture of curd was stirred with the addition of pure dairy culture (bacteria Brevibacterium linens and Pedioccocus acidilactici and yeast culture Candida valida). Later on, the curd was formed into the shape of sticks (approx. $15 \mathrm{~mm}$ height, $15 \mathrm{~mm}$ width and $80 \mathrm{~mm}$ depth). After the 
forming, the mass was dried at $22 \pm 2^{\circ} \mathrm{C}(80-85 \% \mathrm{RH})$ for 2 days (first stage of ripening; target moisture content $64-65 \%$ ). During the first stage of ripening, yeast culture appeared on the surface of the cheese. This culture decreases the acidity of curd and thus modifies the conditions for optimum growth of Brevibacterium linens. Subsequently, the oxidation yeast culture (film of the surface microbiota) was removed from the cheese blocks by means of rinsing (water temperature of $\left.15-17^{\circ} \mathrm{C}\right)($ Fox $\boldsymbol{e t ~ a l . , 2 0 0 4})$. The rinsed blocks of cheese ripened for another 5 days in ripening boxes at a temperat ure of $18-20^{\circ} \mathrm{C}$. The blocks were turned over every day in order to ensure optimum growth of aerobic proteolytic microflora covering the whole surface of the cheese. The actual sampling of the intermediate products of the cheeses was performed on the $1 \mathrm{st}$ (after the forming of the blocks, sample code 1P),3rd (after drying, sample code 3P) and 7th day (after packing, sample code 7P) after the start of the production. Furthermore, a ripening/st orage experiment was st arted from the point of cheese packing. The cheeses ripened/were stored at $8 \pm 2^{\circ} \mathrm{C}$ (which corresponds to the st andard process in retail). The sampling was performed on the $1 \mathrm{st}, 7 \mathrm{th}, 14 \mathrm{th}$, 21 st, 28th, 35th and 42 nd day of st orage (after production, sample codes $1 \mathrm{~S}, 7 \mathrm{~S}$, $14 \mathrm{~S}, 21 \mathrm{~S}, 28 \mathrm{~S}, 35 \mathrm{~S}$ and $42 \mathrm{~S}$ ). The whole experiment was done with 3 batches which were the same as those in the sampling of intermediate products.

\section{Determination of the free amino acid content}

The content of twenty-t wo free amino acids and their derivates (aspartic acid, threonine, serine, asparagine, glut amic acid, glut amine, proline, glycine, alanine, valine, methionine, cysteine, isoleucine, leucine, tyrosine, phenylalanine, lysine, histidine, arginine, ornithine, citrulline, $\gamma$-aminobut yric acid) was determined by ion-exchange chromatography (AAA400 Amino Acid Analyser; Ingos, Prague, Czech Republic) as reported by Buňková $\boldsymbol{e t ~ a l . ~ ( 2 0 0 9 ) ~ a n d ~ P a c h l o v a ́ ~} \boldsymbol{e t}$ al. (2011). The samples were lyophilised on the day of the collection. Each sample was extracted threetimes. Each extract was analysed twice. The reagents for the preparation, separation and analysis of the samples were obtained from Ingos (Prague, Czech Republic). The standards were purchased from Sigma Aldrich (St. Louis, MO, USA).

\section{Sensory analysis}

The sensory evaluation of the samples was performed by 24 selected assessors (employees and students of the Faculty of Technology, Tomas Bata University in

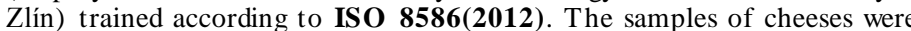
evaluated in a sensory laboratory with booths. All the samples were labelled with codes and served randomly at $20 \pm 1^{\circ} \mathrm{C}$. Nine sensory attributes (consistency of the surface, colour of the surface, flavour, taste, salty, off-flavour, bitterness, sourness and the overall profile of the product) were assessed on a five-point ordinal scale. The sensory analysis was performed only during the ripening period (from 7 th to 42 nd day of storage).

\section{Statistical analysis of the data}

The Kruskall-Wallis and Wilcoxon tests were used to evaluate the following data: the results of the sensory analysis and the content of free amino acids (Agresti, 1984). Pearson's correlation coefficients (r) between the ripening period and free amino acid content and data obtained from the sensory analysis were employed for the evaluation of the results (only the data from the storage period from 7 th to 42 nd day were ev aluated). The dat a obtained in the experimen were processed by means of Unistat 5.5 statistical software (Unistat Ltd., London, UK).

\section{RESULTS AND DISCUSSION}

Proteolitic processes, including the release of free amino acids from the protein matrix, result mainly from the activity of the enzymatic apparatus of the SLAB and NSLAB present. The total FAA content was slightly increased within the $7-$ day production (from $1.8 \mathrm{~g}^{\mathrm{kg}} \mathrm{kg}^{-1}$ in $1 \mathrm{P}$ day to $4.2 \mathrm{~g}^{\mathrm{kg}} \mathrm{kg}^{-1}$ in $7 \mathrm{P} ; \mathrm{P}<0.05$ ). The growth dynamics of the total FAA content increased during the 42-day storage period, when the total FAA content was $30.3 \mathrm{~g} \cdot \mathrm{kg}^{-1}$ in $42 \mathrm{~S}$ of storage $(\mathrm{P}<0.05)$ The development of the individual FAA content within the production and ripening is shown in Figure 1 and Figure 2. During the production, there was an even increase in the content of the individual FAA (Figure $1 ; \mathrm{P}<0.05$ ). Within the production period (from $1 \mathrm{P}$ to $7 \mathrm{P}$ ), the strongest release of lysine, $\gamma$-aminobut yric acid, valine, leucine and proline occurred $(\mathrm{P}<0.05)$. On the other hand, the arginine content was decreasing during the production $(\mathrm{P}<0.05)$ (Pachlová et al., 2013).

The development of FAA content within the ripening period was very slow in the first month of storage (Figure $2 ; \mathrm{P}<0.05$ ). However, after 4 weeks of ripening the intensity of FAA releasing accelerated significantly (Figure 2; $\mathrm{P}<0.05$ ) Compared with sampling in 28 S of ripening $(\mathrm{P}<0.05)$, the content of some FAA doubled or even tripled in the end of experiment (sampling in 42S). The biggest increase in the individual FAA content was observed in lysine, methionine, asparagine, glumanine, glutamic acid, leucine and valine (Figure 2). The development of the individual FAA content positively correlated with the ripening period $(\mathrm{r}=0.8612-0.9229$ for most of theFAA; $\mathrm{r}=0.7734$ for arginine; $\mathrm{P}<0.01)$.

The different development of arginine content (within the production as well as the ripening period) in comparison with the other FAA could lie in the use of arginine by lactic acid bacteria ( $\mathrm{LAB}$ ) for the production of energy while producing ammonia, ornithine and $\mathrm{CO}_{2}$ at the same time (McSweeney and Sousa, 2000). Thus it can be supposed that two reactions were in progress at the same time: (i) release of arginine by means of SLAB and/or NSLAB peptidases; and simult aneously (ii) conversion of arginine causing energy production (Tonon and Lon vaud-Funel, 2000). This statement can be supported by a significant increase in ornithine content not only during the production but also within the ripening period $(\mathrm{P}<0.05)$. Also, low concentrations of citrulline - an intermediate product of the conversion of arginine to ornithine (Christensen et al., 1999) were detected during the production and ripening period (Figures 1 and 2). Towards the end of the ripening process (between sampling in $28 \mathrm{~S}$ and $42 \mathrm{~S}$ ), a slight increase in arginine content was observed in comparison with $1 \mathrm{~S}-21 \mathrm{~S}$. This could be explained by the accelerating cell lysis and lowering amount of the microflora present (both SLAB and NSLAB) at an advanced stage of ripening resulting in a lower need for energy by this metabolic pathway (Law, 2010, Komprda et al., 2008, Bergamini et al., 2006)

Secondary cultures on surface of cheese especially Brevibacterium linens are responsible for intensive proteolysis in smear cheese. Free amino acids (FAA) as the final products of proteolysis are important precursors of sensory active compounds (Smit et al.,2000; Ardö, 2006; Pachlová et al., 2013). The main precursors of sensory active compounds are phenylalanine, tyrosine, tryptophan and branched amino acids such as leucine, isoleucine and valine. Significant amounts of these FAA could lead to the development of the distinctive odour of "Olomoucké tvarůžky"(PGI). Moreover, methionine and its derivates - sulphur compounds, play an important role in the production of soft smear cheese aroma (Yvon and Rijnen, 2001, Pachlová et al., 2013). The main sensory active compounds derived from methionine are methional, methanethiol and its oxidation products such as dimethyldisulphide and dimethyltrisulfide Brevibacterium linens is responsible for production of volatile sulphu compounds in smear cheese (Marilley and Casey, 2004, Bockelmann et al., 2005). FAA themselves can also influence the organoleptic properties: phenylalanine, methionine, valine etc. by their bitterish flavour and aspartic or glut amic acids by their sour flavour. Amino acids such as leucine and glycine can also affect sweet flavour. 


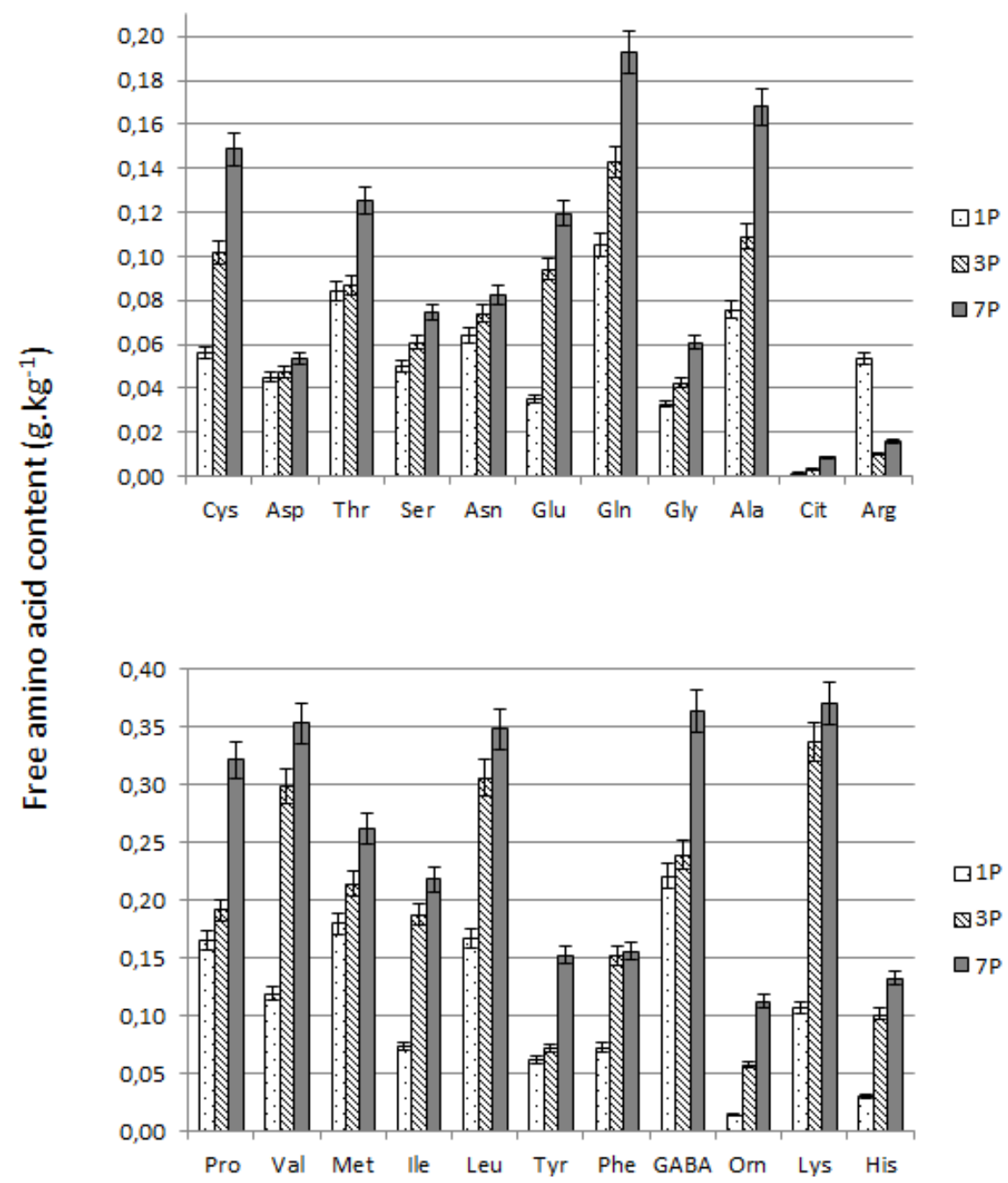

Figure 1 Development of individual free amino acid contents (g-kg-1) during production of "Olomoucké tvarůžky" cheese (PGI): $1 \mathrm{P}-1$ st day of production, $3 \mathrm{P}-3$ rd day of production and $7 \mathrm{P}-7$ th day of production. The values of amino acid content are expressed as means; the bars represented S.D. $(n=18)$.

The development of organoleptic properties (including the correlation coefficients r) during the ripening period of "Olomoucké tvarůžky" (PGI) is illustrated in Table 1. The intensity of flavour and taste was increasing during the storage period $(\mathrm{P}<0.05)$. In the beginning of ripening (from sampling in $1 \mathrm{~S}$ to 14 Sof storage), the cheese samples were most often evaluated as salty and sour. This evaluation corresponds to the character of "Olomoucké tvarüžky"(PGI) and production technology. During the ripening period, slight degradation in consistency of the surface occurred, which might have partly been caused by ripening in the wrapping foil. The micro-en vironmental conditions created under the wrapping within the ripening period might have influenced the smear cult ure on the surface of the cheese. On the other hand, the ripening wrapping adequately protects the product against secondary contamination and water loss from the top layers of the cheese, which would otherwise get dry.

The overall profile of the product was improving with the stage of ripening. Within the storage period of $21 \mathrm{Sto} 35 \mathrm{~S}$, the product was evaluated as good and in the end of experiment (sampling in 42S) it was classified as very good. On the other hand, the assessors noticed slight bitterness within the ripening period. Mainly the low-molecular casein hydrolysates have a tendency to turn bitter, which is caused by a higher content of hydrophobic amino acids (Yvon and Rijen, 2001). The development of cheese bitterness could have also been affected by the content of phenylalanine, which was increasing dramatically from the 35 th day of ripening $(35 \mathrm{~S})$. 


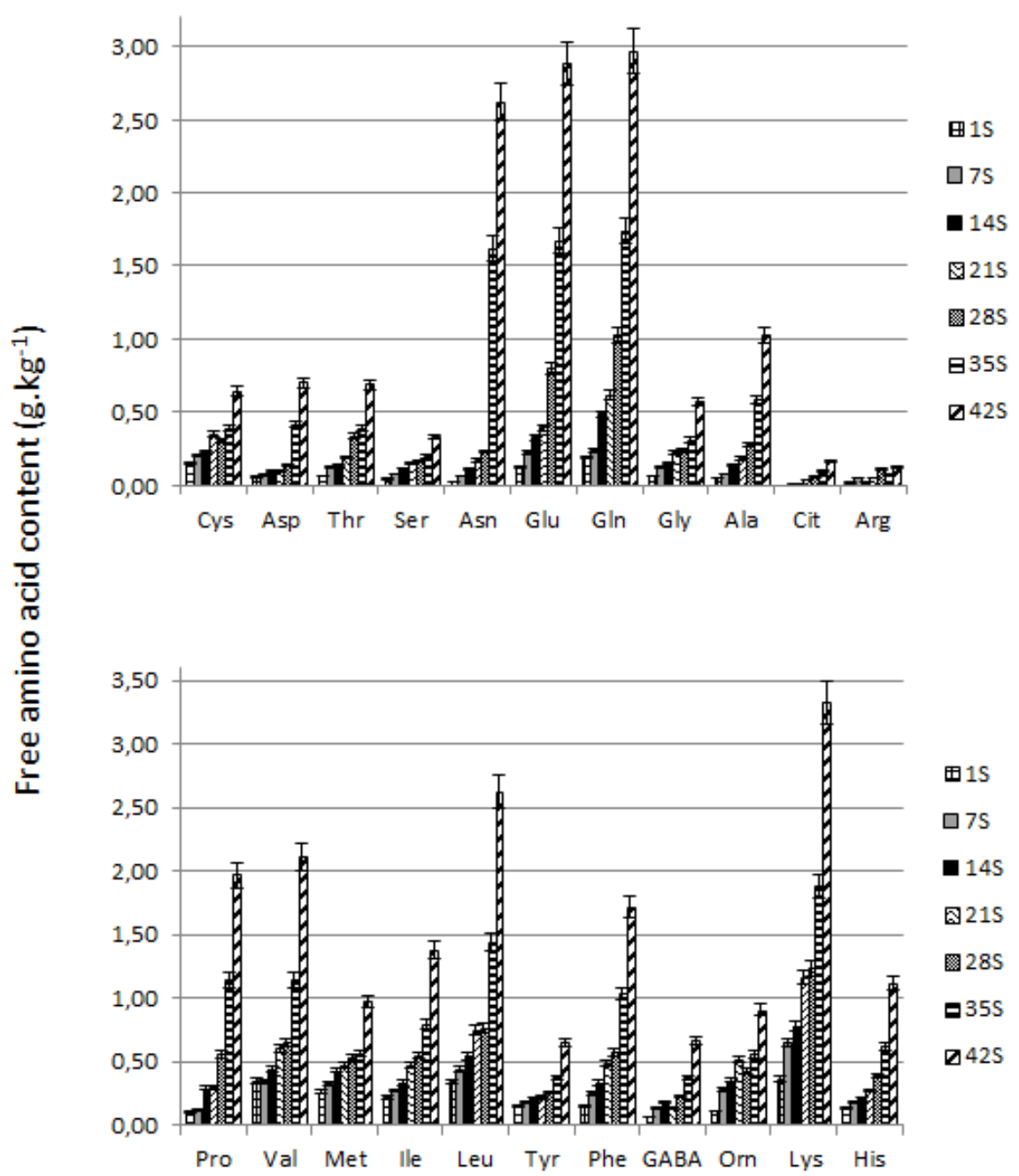

Figure 2 Development of individual free amino acid contents ( $\mathrm{g} \cdot \mathrm{kg}-1)$ during ripening of "Olomoucké tvarǔžky" cheese (PGI; 0R-42R). The values of amino acid content are expressed as means; the bars represented S.D. $(\mathrm{n}=18)$.

Table 1 Results (expressed as median) of the sensory analysis of tested "Olomoucké tvarůžky" cheese (PGI) during cheese ripening ( $7-42$ days; $7 \mathrm{R}-42 \mathrm{R})^{*}$

\begin{tabular}{lllllllc}
\hline \multirow{2}{*}{ Sensory attribute } & \multicolumn{7}{l}{ Storage period (days) } \\
\cline { 2 - 7 } & $\mathbf{7 S}$ & $\mathbf{1 4 S}$ & $\mathbf{2 1 S}$ & $\mathbf{2 8 S}$ & $\mathbf{3 5 S}$ & $\mathbf{4 2 S}$ & $\begin{array}{c}\text { Correlation } \\
\text { coefficient (r) ** }\end{array}$ \\
\hline Consistency of the surface & 1 & 1.5 & 2 & 2 & 2 & 2 & 0.8305 \\
Colour of the surface & 2 & 1.5 & 2 & 2 & 2 & 2 & 0.3928 \\
Flavour & 2 & 2 & 2 & 3 & 3 & 3 & 0.8281 \\
Taste & 1 & 1,5 & 2 & 3 & 3 & 3 & 0.9411 \\
Salty & 2 & 1 & 1 & 1 & 1 & 2 & -0.3928 \\
Off-flavour & 1 & 1 & 1 & 1 & 1 & 1 & 0.6547 \\
Bitterness & 1 & 1 & 1 & 1 & 1 & 2 & 0.6547 \\
Sourness & 3 & 3.5 & 3 & 2.5 & 2.5 & 3 & -0.4971 \\
Overall profile & 4 & 3.5 & 3 & 2.5 & 2.5 & 2 & -0.9805 \\
of the product & & &
\end{tabular}

* Used ordinal scales: Consistency of the surface: 1 - smooth and uniform surface to 5 - absolutely unacceptable with large cracks or lumps. Colour of the surface: 1 - very light and white to 5 - very dark with atypical shades. Flavour: 1 - slight flavour to 5 -very strong flavour. Taste: 1 - insipid to 5 - very strong taste. Salty: 1 - very salty taste to 5 -salt-free. Off-flavour: $1-$ no off-flavour to $5-$ strong off-flavour. Bitterness: 1 - no bitterness to 5 - very strong intensity. Sourness: 1 - very sour taste to 5 - slightly acidic taste. Overall profile of the product: 1 - excellent to 5 - inconvenient.

** Correlation between the level of sensory attributes and the ripening period (in days).

\section{CONCLUSION}

This study describes the development of free amino acid content during the production and ripening of smear acid cheese "Olomoucké tvarůžky" (PGI). Moreover, changes in sensory attributes were observed during the ripening period. Within the production (sampling in $1 \mathrm{P}, 3 \mathrm{P}$ and $7 \mathrm{P}$ ), the content of the individual FAA was increasing evenly. The only exception was arginine content, which was decreasing during the production $(\mathrm{P}<0.05)$. The development of the individual FAA content was increasing during ripening and positively correlated with the ripening period. Changes in content of individual free amino acids are important due to possible formation of sensory active compounds during cheese ripening. Theintensity of flavour and taste was increasing during the ripening period, mainly from the 28 th day of ripening $(28 \mathrm{~S})$. The overall profile of the product was improving with the stage of ripening, although the assessors noticed an increase in bitterness in the last week of ripening. 
Acknowledgments: This work was supported by The National Agency for Agriculture Research, project No. QJ1210300, The Complex Sustainable Systems programme and the Internal Grant project of Tomas Bata University in Zlín No. IGA/FT/2012/026 funded from the resources for specific research.

\section{REFERENCES}

AGRESTI, A. (1984). Analysis of ordinal categorical data. New York, USA: John Wiley\&Sons, Inc., 284p

ARDÖ, Y. (2006). Flavour formation by amino acid cat abolism. Biotechnology Advances, 24, 238-242. http://dx.doi.org/10.1016/j.biotechadv.2005.11.005 BERGAMINI, C. V., HYNES, E. R., ZALAZAR, C. A. (2006). Influence of probiotic bacteria on the proteolysis profile of a semi-hard cheese. International Dairy Journal, 16, 856-866. http://dx.doi.org/10.1016/j.idairyj.2005.09.004 BOCKELMANN, W., WILLEMS, K. P., NEVE, H., HELLER, K. H. (2005). Cult ures for the ripening of smear cheeses. International Dairy Journal, 15, 719 732. http://dx.doi.org/10.1016/j.idairyj.2004.08.022

BUŇKOVÁ, L., BUŇKA, F., HLOBILOVÁ, M., VAŇÁTKOVÁ, Z. NOVÁKOVÁ, D., DRÁB, V. (2009). Tyramine production of technological important strain of Lactobacillus, Lactococcus and Streptococcus. European Food Research and Technology, 229, 533-538. http://dx.doi.org/10.1007/s00217-009-1075-3

CHRISTENSEN, J. E., DUDLEY, E. G., PEDERSON, J. A., STEEL, J. L. (1999). Peptidases and amino acid cat abolism in lactic acid bacteria. Antonie van Leeuwenhoek, 76, 217-246. http://dx.doi.org/10.1023/A:1002001919720 ISO Standards Mo. 8586 (2012). Sensory analysis - General guidance for the selection, trainning and monitoring of selected assessors and expert sensory assessors. Geneva: International Organization for Standardization.

FOX, P. F., McSWEENEY, P. L. H., COGAN, T. M., Guinee, T. P. (2004) Cheese Chemistry, Physics and Microbiology: Volume 2 Major Cheese Groups. (3rd ed.). London, UK: Elsevier Academic Press.

IRLINGER, F., YUNG, S. A. Y. I., SARTHOU, A. M., DELBÈS-PAUS, C., MONTEL, M. C., COTON, E., COTON, M.,HENLICK, S. (2012). Ecological and aromaticimpact of two Gram-negative bacteria (Psychrobacter celer and Hafnia alvei) inoculated as part of the whole microbial community of an experimental smear soft cheese. International Journal of Food Microbiology, 153,332-338. http://dx.doi.org/10.1016/j.ijfoodmicro.2011.11.022

KOMPRDA, T., BURDYCHOVÁ , R., DOHNAL, V., CWIKOVÁ, O., SLÁDKOVÁ, P., DVOŘÁČKOVÁ, H. (2008). Tyramine production in Dutchtype semi-hard cheese from two different producers. Food Microbiology, 25 , 219-227. http://dx.doi.org/10.1016/j.fm.2007.11.006

LAW, B. (2010). Cheese adjunct cultures. The Australian Journal of Dairy Technology, 65, 45-49.

MARILLEY, L., CASEY, M. G. (2004). Flavours of cheese products: metabolic pathways, analytical tools and identification of producing strains. International Journal of Food Microbiology, 90, 139-159. http://dx.doi.org/10.1016/S0168 1605(03)00304-0

MCSWEENEY, P. L.H., SOUSA, M. J. (2000). Biochemical pathways for the production of flavour compounds in cheeses during ripening: A review. Lait, 80, 293-324.

PACHLOVÁ, V., BUŇKA, F., BUŇKOVÁ, L., WEISEROVÁ, E., BUDINSKÝ, P., ŽALUDEK, M., KRÁČMAR, S. (2011). The effect of three diferent ripening/storage conditions on the distribution of selected parameters in individual parts of Dutch-type cheese. International Journal of Food Science and Technology, 46, 101-108. http://dx.doi.org/10.1111/j.1365-2621.2010.02460.x PACHLOVÁ, V., BUŇKA, F., CHROMEČKOVÁ, M., BUŇKOVÁ, L., BART ÁK, P.,POSP ÍŠLL, P. 2013. The development of free amino acids and volatile compounds in cheese 'Olomoucké tvarǔžky' (PGI) during ripening. Internationla Journal of Food Science and Technology, 48, 1868-1876. http://dx.doi.org/10.1111/ijfs.12164

PALENCIA, P. F., PLAZA, M., MOHEDANO, M. L., MART ÍNEZ-CUEST A, M. C., REGUENA, T., LÓPEZ, P., PALÁEZ, C. (2004). Enhancement of 2 methylbutanal formation in cheese by using a fluorescently tagged Lacticin 3147 producing Lactococcus lactis strain. International Journal of Food Microbiology, 93, 335-347. http://dx.doi.org/10.1016/j.ijfoodmicro.2003.11.018

RATTRAY, F. P.,Fox, P.F. (1999). Aspects of enzymology and biochemical properties of Brevibacterium linens relevant to cheese ripening: a review. Joumal of Dairy Science, 82, 891-909.

SABLÉ, S., COTTENCEAU, G. (1999). Current knowledge of soft cheese flavour and related compounds. Journal of Agriculture and Food Chem istry, 47, 4825-4836. http://dx.doi.org/10.1021/jf990414f

SMIT, G., SMIT, B. A., ENGELS, W. J. M. (2005). Flavour formation by lactic acid bacteria and biochemical flavour profiling of cheese products. FEMS Microbiology Reviews, 29, 591-610. http://dx.doi.org/10.1016/j.femsrc.2005.04.002

SMIT, G., VERHEUL, A., KRANENBURG, R., AYAD, E., SIEZEN, R., ENGELS, W. (2000). Cheese flavour development by enzymatic conversions of peptides and amino acids. Food Research International, 33, 153-160. http://dx.doi.org/10.1016/S0963-9969(00)00029-6
TONON, T., LONVAUD-FUNEL, A. (2000). Metabolism of arginine and its positive effect on growth and revival of Oenococcus oeni. Journal of Applied Microbiology, 89, 526-531. http://dx.doi.org/10.1046/j.1365-2672.2000.01142.x WILLIAMS, A. G., BEATTIE, S. H., BANKS, J. M. (2004). Enzymatic involved in flavour formation by bacteriaisolated from the smear population of surfaceripened cheese. International Journal of Dairy Technology, 57, 7-13. http://dx.doi.org/10.1111/j.1471-0307.2004.00115.x

YVON, M., RIJNEN, L. (2001). Cheese flavour formation by amino acid catabolism. International Dairy Journal, 11, 185-201. http://dx.doi.org/10.1016/S0958-6946(01)00049-8 